\title{
Uwagi na temat roli pracodawcy użytkownika jako „pracodawcy pośredniego" w kształtowaniu sprawiedliwych stosunków pracy tymczasowej
}

\begin{abstract}
Praca jest jednym z tych aspektów, aspektem odwiecznym i pierwszoplanowym, zawsze aktualnym i wciąż na nowo domagającym się, by o niej myśleć i świadczyć. Coraz to nowe bowiem powstają pytania i problemy, coraz nowe rodzą się nadzieje, ale także obawy i zagrożenia, związane z tym podstawowym wymiarem ludzkiego bytowania [...].
\end{abstract}

(Jan Paweł II, Laborem exercens, 1) ${ }^{1}$

\section{Uwagi wstępne}

Patrząc z perspektywy minionych wieków, należy traktować prawo pracy jako zdobycz cywilizacyjną. Reguluje ono bowiem stosunki społeczne związane $z$ pracą najemną, mając w szczególności na uwadze ochronę jej wykonawcy. Przypomnieć w tym miejscu trzeba, że przez wiele stuleci to konstrukcja locatio conductio operarum służyła za podstawę świadczenia pracy przez człowieka. Sama praca traktowana była wówczas jako towar, którego cenę kształtowała wolnorynkowa gra popytu i podaży ${ }^{2}$. Zupełnie pominięto w tej konstrukcji społeczny aspekt pracy ludzkiej. Dodatkowo, aż do czasu rozwoju kapitalistycznej produkcji wielkoprzemysłowej, praca najemna miała niewielkie znaczenie

* Dr Magdalena Paluszkiewicz, Katedra Prawa Ubezpieczeń Społecznych i Polityki Społecznej, Wydział Prawa i Administracji, Uniwersytet Łódzki, 90-232 Łódź, ul. Kopcińskiego 8/12.

1 JAN PAWEt II, Laborem exercens - tekst i komentarz, red. ks. J. Chmiel, ks. S. Ryłko, Kraków 1983. Wszystkie cytaty opatrzone skrótem tytułu (LE) pochodzą z tego wydania.

2 K. Kolańczyk, Prawo rzymskie, Warszawa 2000, § 135, 4. 
gospodarcze ${ }^{3}$. Dopiero zatrudnianie rzeszy robotników spowodowało konieczność rezygnacji z anachronicznego kontraktu między locatorem i conductorem na rzecz umowy, gwarantującej minimalne standardy socjalne dla wykonawców pracy. Pojawiające się wówczas ustawodawstwo przemysłowe, regulujące np. maksymalny czas pracy poszczególnych kategorii pracowników, dało początek nowej gałęzi prawa - prawu pracy ${ }^{4}$. Główną podstawą świadczenia pracy najemnej stała się umowa o pracę, gwarantująca ochronę publicznoprawną pracownika przed wyzyskiem, jak również zapewniająca mu względną życiową stabilizację.

Genetyczne związki prawa pracy ze stosunkami przemysłowymi powodują, że ta gałąź prawa musi nadążać za nieustannymi zmianami gospodarczymi i społecznymi. Turbulencyjność otoczenia rynkowego, w którym funkcjonują pracodawcy tworzący miejsca pracy, wymaga uwzględnienia także ich interesów przez ustawodawstwo pracy. Stąd właśnie wywodzą się tendencje liberalizacji rozwiązań prawnych, które dotyczą stabilizacji zatrudnienia oraz ochrony socjalnej pracownika w ramach stosunku pracy. Dobitnym wyrazem owej liberalizacji jest ekspansja różnorodnych nietypowych (elastycznych) form zatrudnienia.

Ich nietypowość wyraża się w odejściu od tradycyjnego paradygmatu stosunku pracy, rozumianego jako wykonywanie pracy na rzecz pracodawcy przez nieokreślony czas, w pełnym wymiarze czasu pracy oraz w zakładzie pracy tegoż pracodawcy. Powszechnie przyjmuje się, że każda forma zatrudnienia nieposiadająca co najmniej jednej ze wskazanych cech, jest formą zatrudnienia nietypowego ${ }^{5}$. Autorka pragnie skupić uwagę na jednej $z$ nich, mianowicie na pracy tymczasowej.

W związku z pracą tymczasową powstają istotne wątpliwości dotyczące sposobu traktowania pracy ludzkiej. Mechanizm, zgodnie z którym pracownik kierowany jest do pracy na rzecz i pod kierownictwem innego niż pracodawca podmiotu (o czym będzie jeszcze mowa), przywodzi na myśl powszechną w starożytności konstrukcję najmu niewolnika obcego. Był to $w$ istocie najem rzeczy - umowa zawierana między właścicielami niewolników, ale oczywiście bez udziału samych wykonawców pracy ${ }^{6}$. Kontrowersyjne we wskazanym kontekście jest również uzależnienie zatrudnienia tymczasowego od uwarunkowań ściśle ekonomicznych, co wiąże się z zatrudnianiem, a wkrótce potem - ze zwalnianiem pra-

${ }^{3}$ „Instytucje średniowieczne prawa lennego, zależność chłopska, reglamentacja bardzo szczegółowa pracy przemysłowej, tak opanowały stosunki, w których jeden człowiek jest obowiązany do spełniania usług na rzecz drugiego za wynagrodzeniem lub za inne korzyści, że dla podstawowych form prawa rzymskiego nie było prawie miejsca". F. Zoll, Prawo pracy w biegu wieków, odbitka z „Rocznika Prawniczego Wileńskiego”, 1930, s. 2.

4 K. SójKa-Zielińska, Historia prawa, Warszawa 1993, s. 271.

5 Por. D. Makowski, Praca tymczasowa jako nietypowa forma zatrudnienia, Warszawa 2006, s. $14-15$ i cyt. tam literatura.

${ }^{6}$ K. KolañCZYK, op. cit., § 135, 4a. 
cownika tymczasowego ${ }^{7}$. W konsekwencji realne wydaje się zagrożenie powrotu do traktowania pracy w sposób przedmiotowy - jako towaru wymienianego za wynagrodzenie. Ostrzeżenie przed niebezpieczeństwem traktowania pracy ludzkiej jako „towaru” lub anonimowej „siły roboczej” znaleźć możemy w tekście encykliki Laborem exercens Jana Pawła II (LE 7).

Zatrudnienie tymczasowe niejednokrotnie w literaturze prawniczej ${ }^{8}$, a jeszcze częściej w języku potocznym ${ }^{9}$, określane jest mianem leasingu pracowniczego, a także wynajmu (wypożyczania) pracowników. W tę konwencję wpisuje się również określenie języka prawnego „pracodawca użytkownik”, pochodzące z ustawy z dnia 9 lipca 2003 r. o zatrudnianiu pracowników tymczasowych ${ }^{10}$. Użytkowanie jest instytucją prawa rzeczowego. W związku z taką nomenklaturą powstaje skojarzenie, że przedmiotem użytkowania jest pracownik tymczasowy. Wnioskowanie to zdaje się potwierdzać sama konstrukcja zatrudnienia tymczasowego, gdzie pracownik tymczasowy staje się niejako „składnikiem” usługi realizowanej w warunkach rynkowych między dwoma przedsiębiorcami. Można dokonać porównania takiego mechanizmu do tego, o którym wspomina Papież - „człowiek zostaje potraktowany jako narzędzie produkcji, podczas gdy powinien on - on jeden, bez względu na to, jaką pracę wypełnia - być traktowany jako jej sprawczy podmiot, a więc właściwy sprawca i twórca" (LE 7).

Powstaje więc pytanie, od czego, a w zasadzie od kogo uzależnione jest takie przedmiotowe traktowanie pracownika w przypadku tej formy zatrudnienia? Wydaje się, że zasadnicze znaczenie mają w tym zakresie dwa czynniki: po pierwsze - polityka prawa przyjęta przez ustawodawcę, a po drugie - polityka stosowania tego prawa przez konkretne podmioty. W przypadku zatrudnienia tymczasowego polityka stosowania prawa zależy w zasadzie od jednego podmiotu. Jest nim agencja pracy tymczasowej, która formalnie jest pracodawcą, zatem nawiązując stosunek pracy, stosuje regulację zatrudnienia tymczasowego. W rzeczywistości to jednak podmiot niebędący pracodawcą - pracodawca użytkownik - oddziałuje za pośrednictwem agencji na stosunek pracy tymczasowej, czyli wpływa na sposób stosowania przez nią konkretnych przepisów prawa. O pośrednim oddziaływaniu na stosunki zatrudnienia wspomina Jan Paweł II w encyklice Laborem exercens - podmiot oddziałujący określając mianem pracodawcy pośredniego.

7 Zjawisko to określa się w literaturze prawniczej jako hiring and firing. Zob. M. MoszYŃskı, Praca tymczasowa - aspekty ekonomiczne i zatrudnieniowe, „Praca i Zabezpieczenie Społeczne” 2004, nr 10, s. 8.

${ }^{8} \mathrm{~Np}$. E. BAK, Elastyczne formy zatrudnienia, Warszawa 2006, s. 21-29; A. ZaWADZKA, Leasing pracowniczy - korzystanie z pracowników tymczasowych, „Rachunkowość Budżetowa” 2004, nr 5, passim.

${ }^{9}$ Np. J. GóRA, Jak wynająć pracownika na tydzień, miesiąc lub rok, „Gazeta Prawna”, 26 maja 2008 r.; Pożyczony człowiek, „Gazeta Wyborcza”, 12.04.1999, dodatek do „Praca”, nr 85, s. 2; P. ZвRoJA, Personel w leasingu, „Rzeczpospolita”, 24.10.2003, nr 249 (6629); Z. JóżwiAK, Człowiek z wypożyczalni, „Rzeczpospolita”, 20.11.2001, nr 39271 (6044).

10 Dz. U. nr 166, poz. 1608 ze zm., dalej: ustawa o zatrudnianiu pracowników tymczasowych. 
W związku z tym, poniższe rozważania będą stanowić próbę odpowiedzi na dwa zasadnicze pytania. Po pierwsze, czy można utożsamiać pracodawcę użytkownika w zatrudnieniu tymczasowym z pracodawcą pośrednim w rozumieniu nadanym przez encyklikę Laborem exercens? Po drugie zaś, czy i w jaki sposób pracodawca użytkownik realizuje funkcje pracodawcy pośredniego, które określił Papież Jan Paweł II we wspomnianym już dokumencie?

\section{Koncepcja pracodawcy pośredniego według encykliki i jej przydatność w analizie stosunku pracy tymczasowej}

Papież Jan Paweł II na gruncie encykliki wyodrębnia dwa rodzaje pracodawców - pracodawcę bezpośredniego i pracodawcę pośredniego. Pracodawcą bezpośrednim określa osobę lub instytucję, z którą pracownik zawiera bezpośrednio umowę o pracę pod pewnymi warunkami, zaś przez pracodawcę pośredniego - zasadniczo „wiele zróżnicowanych czynników, stojących poza pracodawcą bezpośrednim i wywierających określony wpływ na to, w jaki sposób kształtuje się umowa o pracę, a w konsekwencji mniej lub bardziej sprawiedliwe stosunki w dziedzinie pracy ludzkiej" (LE 16). W kolejnym punkcie encykliki pojęcie to zostaje uszczegółowione przez wskazanie, że za pracodawcę pośredniego należy uznać osoby i instytucje różnego typu i ustalane przez nie zasady postępowania, określające społeczno-ekonomiczny ustrój państwa i jego konsekwencje, a także zbiorowe umowy o pracę.

Bardzo ważnym zagadnieniem, z punktu widzenia podjętych tu rozważań, jest rola pracodawcy pośredniego. Polega ona, według Papieża, na oddziaływaniu na różne aspekty stosunku pracy i warunkowaniu w ten sposób postępowania pracodawcy bezpośredniego przy ustalaniu przez niego warunków zatrudnienia (LE 17). Papież zwraca zatem uwagę na to, że bardzo wiele uwarunkowań wpływa na politykę zatrudnienia i trzeba mieć je wszystkie na uwadze, chcąc ukształtować ją prawidłowo $z$ etycznego punktu widzenia. W konsekwencji politykę zatrudnienia należy uznać za etyczną, gdy w pełni respektuje ona obiektywne prawa człowieka pracy. Jednak, jak słusznie wskazuje Papież, polityka zatrudnienia jest uzależniona przede wszystkim od rachunku ekonomicznego, który determinuje działania w celu maksymalizacji zysku. Stąd też formułuje postulat, aby podstawowe kryterium kształtowania całej ekonomii w wymiarze każdego społeczeństwa i państwa stanowił wzgląd na obiektywne uprawnienia człowieka pracy. Dlatego określając rolę pracodawcy pośredniego wskazuje się, że wywiera on doniosły wpływ na „realizację pełnego poszanowania uprawnień człowieka pracy, które stanowią kluczowy element całego społecznego ładu moralnego" (LE 17).

Pojęcie pracodawcy pośredniego w kształcie nadanym w encyklice uważa się za mało przydatne na gruncie nauki prawa pracy, ze względu na jego 
wielopoziomowość i stopniowalność ${ }^{11}$. Jest ono mało precyzyjne z powodu połączenia elementów o zróżnicowanym statusie ontologicznym, takich jak: osoby, instytucje, organizacje międzynarodowe, zespoły reguł prawnych oraz zasady postępowania, które kształtują cały ustrój społeczno-ekonomiczny oraz wynikające z niego zasady ${ }^{12}$. Ze wskazanych powodów nie wydaje się możliwe przeniesienie na grunt prawa pojęcia pracodawcy pośredniego w kształcie nadanym przez Papieża. Oznaczałoby to bowiem konieczność znacznego zawężenia tego pojęcia, a w konsekwencji - zniekształcenie jego treści w stosunku do pierwotnego jej zakresu nadanego przez Jana Pawła II $^{13}$. Nie jest to jednak równoznaczne z tym, że owa encyklika nie może zostać wykorzystana w kształtowaniu rzeczywistości prawnej. Stanowi ona dokument o naturze filozoficzno-ideologicznej, wyrażający postulaty społecznej nauki Kościoła katolickiego wobec sposobu postrzegania pracy ludzkiej. Idee i wartości wyrażone w tej „moralnej konstytucji pracy”14 powinny być zatem uwzględniane zarówno w procesie tworzenia, jak i stosowania prawa. Zatem w takim kontekście można rozważać przydatność encykliki Laborem exercens w analizach prawniczych.

Wykorzystując przesłania zawarte we wskazanym dokumencie, przedstawiciele doktryny prawa pracy w większości ograniczali pojęcie pracodawcy pośredniego do państwa ${ }^{15}$. Zabieg ten był w pełni uzasadniony, gdyż jeszcze praktycznie przez dekadę od jej ogłoszenia w Polsce to państwo miało niemalże wyłączny wpływ na pracodawców bezpośrednich poprzez kształtowanie ekonomicznych warunków prowadzenia działalności gospodarczej. Mniejszym natomiast uznaniem cieszył się wówczas pogląd sprzeciwiający się utożsamianiu pracodawcy pośredniego wyłącznie z państwem ${ }^{16}$.

Ustosunkowując się do przedstawionych interpretacji pojęcia „pracodawca pośredni”, należy wyrazić przekonanie o potrzebie rewizji zapatrywania, w świetle którego to przede wszystkim państwo powinno być postrzegane w roli pracodawcy pośredniego. Abstrahując od tego, że sam tekst encykliki nie pozwala na przyjęcie takiej interpretacji ${ }^{17}$, nie można ignorować zmian ustrojowych, jakie zostały wprowadzone w naszym kraju od czasu ogłoszenia tego dokumentu. Przed rokiem 1989 rzeczywiście to państwo w przeważającej mierze kształtowało warunki zatrudnienia pracowników, zarówno jako pracodawca bezpośredni,

11 Tak: W. Sanetra, Pracownicy i pracodawcy. Niektóre podstawowe problemy, pojęcia i konstrukcje, [w:] Pracownicy i pracodawcy, Materiały XVI Zimowej Szkoły Prawa Pracy, Karpacz, marzec 1989, s. 17; B. WAGneR, W sprawie „pracodawcy pośredniego”, „Państwo i Prawo” 1990, nr 10, s. 90, 91.

12 W. Sanetra, op. cit., s. 17-18.

13 Por. B. Wagner, op. cit., s. 91.

14 Tak: T. Lıszcz, Papież Jan Paweł II o pracy - w 25 rocznicę ogłoszenia encykliki „Laborem exercens”, „Praca i Zabezpieczenie Społeczne” 2006, nr 10, s. 7.

15 T. Zieliński, Prawo pracy. Zarys systemu, cz. I, Wrocław 1986, s. 117; W. Szubert, Refleksje nad modelami prawa pracy, „Państwo i Prawo” 1989, nr 10, s. 12.

16 Podobnie: B. WAgner, op. cit., s. 89.

17 Bardziej zgodne z tym dokumentem jest stwierdzenie, że wiele elementów, w tym szczególnie państwo i prowadzona przez nie polityka, oddziałuje na stosunki pracy. 
jak i pracodawca pośredni ${ }^{18}$. W chwili obecnej bardziej prawdziwe wydaje się twierdzenie, że państwo w zasadzie jedynie koryguje niedoskonały wpływ gospodarki rynkowej na stosunki pracy. Czyni to przede wszystkim za pomocą rozmaitych instrumentów prawnych, natomiast tylko w ograniczonym zakresie wykorzystuje mechanizmy ekonomiczne. Rola państwa w procesie tworzenia prawa ma więc charakter raczej instrumentalny - prawo pracy reguluje powstały już stosunek społeczny, nie jest zaś jego źródłem. Ponadto rola państwa w tworzeniu prawa pracy polega również - jak się wydaje - na zapewnianiu ochrony pracownikowi przed bezwzględnymi mechanizmami rynkowymi i na umożliwianiu realizacji jego prawa do pracy. W konsekwencji trzeba stwierdzić, że przemożny wpływ na stosunki pracy mają dziś podmioty prywatne uczestniczące w rynku i to one w pierwszej kolejności - przed państwem - powinny być postrzegane w roli pracodawcy pośredniego. W przeważającej liczbie przypadków państwo jest zmuszone dostosowywać regulację stosunku pracy do ukształtowanych warunkami ekonomicznymi potrzeb tych podmiotów, co następuje najczęściej w formie wspomnianej już liberalizacji w zakresie trwałości więzi prawnej. Powyższe rozważania skłaniają więc do sformułowania, być może kontrowersyjnej, tezy, że to pracodawca użytkownik wywiera wpływ - za pośrednictwem państwa jako regulatora stosunków społecznych - na stosunki pracy tymczasowej ${ }^{19}$. We wskazanej sytuacji można zatem określić pracodawcę użytkownika jako pracodawcę pośredniego w znaczeniu abstrakcyjnym.

Udział pracodawcy użytkownika w kształtowaniu stosunków pracy tymczasowej nie ogranicza się jednak tylko do wpływu na ustawodawstwo pracy. Podmiot ten oddziałuje bowiem również na realizację zindywidualizowanego stosunku pracy. W takim zakresie moglibyśmy go określić mianem pracodawcy pośredniego konkretnego. Ukazując wpływ pracodawcy użytkownika na konkretny stosunek pracy należy zauważyć, że zgodnie z ustawą o zatrudnianiu pracowników tymczasowych pracodawca użytkownik jest podmiotem, do którego agencja pracy tymczasowej kieruje zatrudnionego przez siebie pracownika tymczasowego. Agencja pracy tymczasowej zatrudnia pracownika wyłącznie po to, by skierować go do pracy na rzecz i pod kierownictwem pracodawcy użytkownika. Jest to zatem podmiot, który nie zatrudnia pracownika w sensie prawnym, ponieważ umowa o pracę zostaje zawarta między agencją pracy tymczasowej a pracownikiem tymczasowym. Posługując się nomenklaturą encykliki, moglibyśmy określić agencję pracy tymczasowej jako pracodawcę bezpośredniego. Natomiast pracodawca

18 Zwrócił na to uwagę W. SANETRA, op. cit., s. 19.

19 Ustawa z dnia 9 lipca 2003 r. uregulowała zasady zatrudniania pracowników do wykonywania pracy na rzecz innego podmiotu - ta forma zatrudnienia do czasu jej wejścia w życie była stosowana na podstawie zasady swobody umów. Znaczący wpływ pracodawców użytkowników na obecną regulację prawną ilustruje nowelizacja ustawy o zatrudnianiu pracowników tymczasowych - ustawa z dnia 23 października 2009 r. o zmianie ustawy o zatrudnianiu pracowników tymczasowych (Dz. U. nr 221, poz. 1737), która - spełniając wysuwane przez nich postulaty - przedłużyła maksymalny okres wykonywania pracy tymczasowej na rzecz jednego pracodawcy użytkownika z 12 do 18 miesięcy. 
użytkownik, nie zatrudniając pracownika tymczasowego we własnym imieniu, kształtuje warunki jego zatrudnienia po to, by otrzymać efekt w postaci pracy wykonanej w określony sposób, w konkretnym miejscu i czasie, wynikających z jego zapotrzebowania.

Świadczenie pracy na rzecz i pod kierownictwem innego niż pracodawca podmiotu skłania niektórych przedstawicieli doktryny prawa pracy do refleksji, że to agencja pracy tymczasowej jest pracodawcą pośrednim, ponieważ jej rola ogranicza się w sensie faktycznym do prostego pośredniczenia w zatrudnieniu między pracownikiem tymczasowym a pracodawcą użytkownikiem ${ }^{20}$. Dla rozważań tutaj podjętych kluczowe jest znaczenie nadane temu pojęciu przez Papieża Jana Pawła II. W związku z powyższym to pracodawcę użytkownika należy widzieć w roli pracodawcy pośredniego w zatrudnieniu tymczasowym, a to ze względu na wpływ, jaki wywiera on na kształt i sposób realizacji stosunku pracy tymczasowej.

\section{Sposób oddziaływania pracodawcy użytkownika na konkretny stosunek pracy tymczasowej}

Zgodnie z art. 18 ust. 1 ustawy z dnia 20 kwietnia 2004 r. o promocji zatrudnienia i instytucjach rynku pracy ${ }^{21}$, praca tymczasowa jest usługą świadczoną na rynku pracy przez agencje pracy tymczasowej22. Agencja pracy tymczasowej to - w świetle powołanego przepisu - przedsiębiorca, który prowadzi działalność gospodarczą regulowaną. Polega ona na świadczeniu usług w zakresie pracy tymczasowej, a zatem na zatrudnianiu pracowników tymczasowych w celu skierowania ich do wykonywania pracy na rzecz i pod kierownictwem pracodawcy użytkownika. Co szczególnie istotne, agencja świadczy tę usługę dopiero w wyniku zgłoszenia zapotrzebowania przez konkretnego pracodawcę użytkownika. Formalnym tego wyrazem jest zawarcie przez wskazane podmioty umowy o świadczenie usługi w zakresie pracy tymczasowej. Zgodnie z art. 9 ust. 1 ustawy o zatrudnianiu pracowników tymczasowych jej przedmiotem ${ }^{23}$ są min. rodzaj pracy, która ma zostać powierzona pracownikowi tymczasowemu, wymagania kwalifikacyjne konieczne do wykonywania tej pracy, przewidywany okres świadczenia pracy tymczasowej, wymiar czasu pracy oraz miejsce jej wykonywania.

20 W. Sanetra, Praca tymczasowa - zatrudnienie czy pośrednictwo pracy?, [w:] Z zagadnień współczesnego prawa pracy. Księga jubileuszowa prof. H. Lewandowskiego, red. Z. Góral, Warszawa 2009, s. 333-334.

21 Tekst jedn. Dz. U. 2013,r., poz. 674 ze zm., dalej: ustawa o promocji zatrudnienia.

22 Szerzej na ten temat: M. PALUszkIEWICz, Zatrudnienie tymczasowe $w$ polskim prawie pracy - konstrukcja i charakter prawny, Warszawa 2011, s. 92-120.

${ }^{23}$ W przepisie mowa jest wprawdzie o uzgodnieniach stron, ale dotyczą one sposobu realizacji usługi w zakresie pracy tymczasowej przez agencję, stąd zasadne jest, by uznać je za część umowy, o której stanowi explicite art. 25 ustawy o zatrudnianiu pracowników tymczasowych. 
W następstwie uzgodnienia wskazanych elementów agencja poszukuje pracownika o określonych przez pracodawcę użytkownika kwalifikacjach. Swoboda kontraktowa agencji jako pracodawcy bezpośredniego doznaje zatem istotnych ograniczeń. „Dobierając” kandydata do zatrudnienia, kieruje się ona kryteriami wskazanymi przez pracodawcę użytkownika. Podobnie, kształtując w umowie o pracę warunki zatrudnienia pracownika tymczasowego, jest związana ustaleniami poczynionymi uprzednio z pracodawcą użytkownikiem. Poprzez zawarcie umowy o świadczenie usługi $w$ zakresie pracy tymczasowej, zobowiązuje się bowiem do zatrudnienia pracownika o konkretnych kwalifikacjach, na ustalonych warunkach i do skierowania go na określony czas do wykonywania pracy na rzecz pracodawcy użytkownika. W konsekwencji, w chwili nawiązywania umowy o pracę z pracownikiem tymczasowym, warunki świadczenia przez niego pracy są już ustalone, toteż jego pozycja negocjacyjna wydaje się bardzo słaba. W tym kontekście duże znaczenie przypisać należy ustawowym standardom w zakresie kształtowania warunków zatrudnienia tymczasowego, które mają chronić pracownika tymczasowego przed niekorzystnym uformowaniem treści stosunku pracy.

W rezultacie działania prawne agencji czyli bezpośredniego pracodawcy - choć formalnie samodzielne - podejmowane są w interesie pracodawcy użytkownika. Co więcej, realizacja interesu tego podmiotu jest urzeczywistniana przez zabezpieczoną prawem możliwość żądania od agencji, by zatrudniła pracownika tymczasowego na warunkach określonych w umowie o świadczenie usług. Oddziaływanie pracodawcy użytkownika na agencję pracy tymczasowej jest więc prawnie wiążące ${ }^{24}$.

Powyższe rozważania ilustrują wpływ pracodawcy użytkownika przede wszystkim na nawiązanie stosunku pracy w ramach zatrudnienia tymczasowego. Ustalenia dokonane między agencją a tym podmiotem implikują również treść samego stosunku pracy, poprzez konkretyzację poszczególnych uprawnień i obowiązków związanych z wykonywaniem pracy tymczasowej. Rodzaj pracy, czas, miejsce i okres jej wykonywania są - w granicach wyznaczonych przez przepisy prawa pracy - zdeterminowane wolą pracodawcy użytkownika.

Elementem, który upodabnia pracodawcę użytkownika do pracodawcy pośredniego jest pozbawienie go możliwości bezpośredniego oddziaływania na stosunek pracy tymczasowej. Podmiot ten może wpływać na jego treść, ale czyni to wyłącznie za pośrednictwem agencji pracy tymczasowej, która jest zgodnie $z$ art. 1 ustawy o zatrudnianiu pracowników tymczasowych pracodawcą pracownika tymczasowego. Wynika to zasadniczo $z$ faktu, że formalnie przymiot stron stosunku pracy posiadają pracownik tymczasowy i agencja pracy tymczasowej. W konsekwencji, tylko oni mogą w sposób bezpośredni i prawnie wiążący dokonywać zmian treści łączącego ich stosunku prawnego.

\footnotetext{
24 Szerzej na ten temat: M. PALuszkiewicz, op. cit., s. 260-262.
} 
Z powyższego wynika, że choć oświadczenia woli dotyczące nawiązania stosunku pracy i jego treści formalnie składają pracownik tymczasowy i agencja, to faktycznie kryje się za tymi czynnościami prawnymi „wola” pracodawcy użytkownika. Ta sama konstatacja odnosi się również do czasu trwania owego stosunku prawnego. Ustawodawca przewiduje bowiem możliwość zatrudniania pracownika tymczasowego na rzecz jednego pracodawcy użytkownika zasadni$\mathrm{CzO}^{25}$ przez czas maksymalnie 18 miesięcy w okresie 36 miesięcy ${ }^{26}$. Jednocześnie zgodnie z art. 18 ust. 2 ustawy o zatrudnianiu pracowników tymczasowych, pracodawca użytkownik ma prawo zrezygnować z pracy świadczonej przez pracownika tymczasowego. Możliwość realizacji tego uprawnienia jest niezależna od tego, czy termin końcowy umowy o pracę łączącej agencję z pracownikiem tymczasowym już nadszedł. Nie jest również konieczne podawanie jakiejkolwiek przyczyny, która stanowiłaby uzasadnienie dla dokonania takiej rezygnacji. Ponieważ zatrudnienie tymczasowe jest usługą realizowaną na rzecz pracodawcy użytkownika, rezygnacja z niej powoduje po stronie agencji konieczność rozwiązania stosunku pracy z pracownikiem tymczasowym. Odpada bowiem wówczas rzeczywisty cel jego zatrudnienia, jakim jest wykonywanie pracy na rzecz i pod kierownictwem pracodawcy użytkownika. Rozwiązaniem, które umożliwia agencji relatywnie łatwe zakończenie współpracy z pracownikiem tymczasowym jest - przewidziana w art. 13 ust. 2 ustawy o zatrudnianiu pracowników tymczasowych - możliwość wprowadzenia do każdej umowy o pracę na czas określony klauzuli dopuszczającej wcześniejsze rozwiązanie za wypowiedzeniem. Również agencja pracy tymczasowej nie ma obowiązku podawać pracownikowi jakiejkolwiek przyczyny, która uzasadniałaby dokonanie wypowiedzenia. Określenie w umowie jej terminu końcowego nie daje zatem pracownikowi tymczasowemu poczucia stabilizacji, ponieważ pracodawca użytkownik przed jego nadejściem może skorzystać ze swojego ustawowego uprawnienia do rezygnacji27.

Reasumując przeprowadzone rozważania w przedmiocie sposobu oddziaływania pracodawcy użytkownika na realizację stosunku pracy tymczasowej należy zauważyć, że ma ono charakter wielopłaszczyznowy. Podmiot ten nie tylko decyduje o możliwości wykonywania pracy przez konkretnego pracownika tymczasowego, lecz także szczegółowo determinuje sposób jej wykonania. Cechą genetyczną zatrudnienia tymczasowego jest bowiem - zgodnie $z$ art. 1 ustawy o zatrudnianiu pracowników tymczasowych - wykonywanie pracy na rzecz pracodawcy użytkownika. W konsekwencji podmiot ten decyduje w sensie faktycznym o bycie stosunku pracy tymczasowej, jak również w granicach określonych ustawowo - o jego kształcie.

${ }^{25}$ Por. art. 20 ust. 2 ustawy o zatrudnianiu pracowników tymczasowych.

${ }^{26}$ Por. art. 20 ust. 1 ustawy o zatrudnianiu pracowników tymczasowych.

27 Pomijam tu kwestię ochrony trwałości stosunku pracy pracowników tymczasowych. Ponieważ ustawa o zatrudnianiu pracowników tymczasowych tej kwestii nie reguluje, zastosowanie jako lex genaralis znajdzie Kodeks pracy i pozostałe przepisy powszechnego prawa pracy. Por. też art. 6 ustawy o zatrudnianiu pracowników tymczasowych. 


\section{Wpływ pracodawcy użytkownika jako pracodawcy pośredniego na kształtowanie sprawiedliwych stosunków pracy tymczasowej}

Pierwsze zagadnienie, które należy poddać tutaj rozważaniom, to urzeczywistnianie w stosunku pracy tymczasowej uprawnień człowieka pracy. Przypomnieć bowiem należy, że pracodawca pośredni, zgodnie z encykliką Laborem exercens, ma wpływ na ich realizację i w konsekwencji kształtuje mniej lub bardziej sprawiedliwe stosunki w dziedzinie ludzkiej pracy (LE 16).

Rozpocząć należy od analizy pojęcia uprawnień człowieka pracy. Zgodnie z encykliką - „uprawnienia te należy rozpatrywać w kontekście ogółu praw właściwych człowiekowi, z których wiele zostało już proklamowanych przez odnośne instancje międzynarodowe [...]". Wydaje się, że celowe jest ograniczenie rozważań do najbardziej fundamentalnego z nich - czyli prawa do pracy. Dopiero realizacja tego prawa umożliwia skorzystanie z pozostałych uprawnień przysługujących ludziom pracy. Prawo do posiadania pracy Jan Paweł II wyprowadza $z$ „zasady powszechnego używania dóbr, albo inaczej jeszcze i po prostu: z prawa do życia i utrzymania"28. W doktrynie prawa pracy wskazuje się natomiast, że treścią prawa do pracy jest możliwość wykonywania pracy zarobkowej przez jednostkę 29 . Jeden z postulatów wyrażonych w Laborem exercens to stosowanie kryterium realizacji uprawnień ludzi pracy w kształtowaniu przez pracodawcę pośredniego sprawiedliwych stosunków zatrudnienia.

W związku z powyższym konieczne wydaje się podkreślenie obowiązku, jaki Papież Jan Paweł II formułuje w pkt. 14 Encykliki w odniesieniu do właścicieli środków produkcji. Zgodnie z nim, właściciel kapitału nie może go posiadać dla samego posiadania, ani nie wolno mu posługiwać się nim do praktykowania wyzysku pracowników. Ma nim dysponować w ten sposób, by innym ludziom - zwłaszcza zatrudnionym pracownikom - umożliwić zrealizowanie powszechnego prawa do nabywania dóbr i używania ich ${ }^{30}$.

W konsekwencji zadać trzeba pytanie, czy możliwość realizacji uprawnień pracowniczych jest czynnikiem wiodącym, który pracodawca użytkownik bierze pod uwagę oddziałując na stosunki pracy tymczasowej? Czy jednak determinantą jego działań nie są przede wszystkim czynniki ekonomiczne?

Szukając odpowiedzi na te pytania, w pierwszej kolejności należy zwrócić uwagę na sformułowaną w art. 2 pkt 3 ustawy o zatrudnianiu pracowników tymczasowych definicję pracy tymczasowej. Jest nią wykonywanie zadań o charakterze

28 T. LıszCZ, op. cit., s. 3.

29 Z. GórAL, O aktualności traktowania prawa do pracy jako zasady prawa pracy, [w:] Z zagadnień współczesnego prawa pracy..., s. 65.

30 Por. Ks. J. SIEG, Obowiązki i prawa pracodawców i pracowników, [w:] Laborem exercens - tekst i komentarz, red. ks. J. Chmiel, ks. S. Ryłko, Kraków 1983, s. 136-137. 
sezonowym, okresowym, doraźnym, których terminowe wykonanie przez pracowników zatrudnionych przez pracodawcę użytkownika nie byłoby możliwe lub których wykonanie należy do obowiązków nieobecnego pracownika zatrudnionego przez pracodawcę użytkownika. Co więcej, zgodnie z art. 20 wspomnianej ustawy, zatrudnienie tymczasowe na rzecz jednego pracodawcy użytkownika nie może trwać zasadniczo dłużej niż 18 miesięcy w okresie kolejnych 36 miesięcy. W konkluzji należy podkreślić, że zatrudnienie to z istoty rzeczy ma charakter nietrwały. W połączeniu ze wspomnianym wyżej uprawnieniem pracodawcy użytkownika do rezygnacji, praca tymczasowa jawi się jako forma zatrudnienia bardzo ściśle uzależniona od warunków ekonomicznych. Realizacja umówionego zadania zasadniczo oznaczać będzie więc zakończenie zatrudnienia tymczasowego.

Należy jednak podkreślić, że pracodawca użytkownik dysponuje instrumentami prawnymi, umożliwiającymi urzeczywistnianie prawa do pracy pracowników tymczasowych. W związku z powyższym bardzo istotne znaczenie mają rozwiązania ustawowe służące nawiązaniu trwałej więzi prawnej, bezpośrednio między pracownikiem tymczasowym a pracodawcą użytkownikiem po zakończeniu zatrudnienia tymczasowego. W świetle art. 12 ustawy o zatrudnianiu pracowników tymczasowych, ustalenie między agencją a pracodawcą użytkownikiem warunku niezatrudniania pracownika tymczasowego przez pracodawcę użytkownika po zakończeniu wykonywania pracy tymczasowej jest nieważne. Ten sam cel ma spełniać, jak się wydaje, regulacja zawarta w art. 23 ust. 3 wspomnianej ustawy. Przepis ten nakłada na pracodawcę użytkownika obowiązek informowania pracowników tymczasowych, w sposób przyjęty u tego pracodawcy użytkownika, o wolnych stanowiskach pracy, na których zamierza zatrudnić pracowników. Należy jednak wyrazić ubolewanie nad tym, że naruszenie owego obowiązku nie wiąże się z żadnymi prawnymi sankcjami.

Praktykę stosowania przez pracodawców użytkowników polityki urzeczywistniającej uprawnienia ludzi pracy niech zilustrują dane. Z przeprowadzonych w 2013 r. przez Ministerstwo Pracy i Polityki Społecznej badań wynika, że najwięcej - bo $51 \%$ ogólnej liczby pracowników tymczasowych - świadczyło pracę przez okres do 3 miesięcy; na okres od 3 miesięcy do 12 miesięcy zatrudnionych było 40\%; natomiast powyżej 12 miesięcy zaledwie $9 \%{ }^{31}$. Jest sprawą oczywistą, że pracodawcy użytkownicy nie mogą być w żaden sposób przymuszani do stałego zatrudniania dotychczasowych pracowników tymczasowych. Wydaje się jednak, że znacząco oddziałując na kształt regulacji prawnej dotyczącej zatrudnienia tymczasowego, powinni być zainteresowani właściwym jej stosowaniem w praktyce. Ustawodawca uwzględniając w regulacji prawnej wysuwane przez nich postulaty, jak się wydaje moralnie zobowiązał ich do wykorzystywania instytucji zatrudnienia tymczasowego zgodnie z jej przeznaczeniem - to znaczy w związku

${ }^{31}$ Informacja o działalności agencji zatrudnienia w 2013 r., Ministerstwo Pracy i Polityki Społecznej, Warszawa 2014, http://www.psz.praca.gov.pl/main.php?do=ShowPage\&nPID=867743\&pT=details\&sP=CONTENT,objectID,1025055 [dostęp: 8.09.2014]. 
z krótkotrwałym zapotrzebowaniem na pracę. Tymczasem z obserwacji sposobu stosowania przepisów o pracy tymczasowej wynika, że pracownicy tymczasowi zatrudniani są do wykonywania prac, które nie mają charakteru zadaniowego, więc rezultatem zakończenia umowy z jednym pracownikiem jest skierowanie w jego miejsce kolejnego ${ }^{32}$.

\section{Podsumowanie}

Zatrudnienie tymczasowe w Polsce jest formą wykonywania pracy dla około 560 tys.,osób ${ }^{33}$, co stanowi w przybliżeniu $5 \%$ ogółu zatrudnionych ${ }^{34}$. Jego oddziaływanie na rynek pracy jest zatem umiarkowane. Nie oznacza to jednak, że pracownicy tymczasowi mogą być traktowani przedmiotowo, jako narzędzia pracy służące wyłącznie pomnażaniu zysków.

Oceniając państwo jako regulatora stosunków prawnych związanych z zatrudnieniem tymczasowym trzeba zauważyć jego wkład w zabezpieczenie interesów osób wykonujących pracę tymczasową. Pracownicy tymczasowi mają zagwarantowane - na podstawie art. 5 ustawy o zatrudnianiu pracowników tymczasowych - wszelkie uprawnienia, które przysługują pracownikom w tradycyjnym stosunku pracy. Pewne modyfikacje w tym zakresie wykazują ich uprawnienia urlopowe, których realizacja jest uzależniona od czasu pozostawania w dyspozycji pracodawcy użytkownika ${ }^{35}$. Pozytywnie należy również ocenić zabieg ustawodawcy polegający na nadaniu agencji pracy tymczasowej w art. 6 ust. 4 ustawy o promocji zatrudnienia - statusu instytucji rynku pracy. Oznacza to, że poprzez wykonywanie usługi zatrudnienia tymczasowego bierze ona udział w realizacji zadań państwa w zakresie zwalczania bezrobocia.

Oceniając pracodawcę użytkownika jako pracodawcę pośredniego, trzeba niestety sformułować uwagi krytyczne. Przede wszystkim powstaje pytanie, czy w zatrudnieniu trwającym w ponad połowie przypadków przez okres do 3 miesięcy można kształtować sprawiedliwą politykę zatrudnienia? Jest to oczywiście pytanie retoryczne, bowiem $w$ tak krótkim okresie pracownicy tymczasowi nie mają możliwości skorzystania z większości uprawnień zagwarantowanych im przez prawo $\mathrm{w}$ związku z zatrudnieniem $\mathrm{w}$ ramach stosunku pracy.

32 Por. D. Makowskı, Zatrudnianie pracowników tymczasowych, „Praca i Zabezpieczenie Społeczne" 2003, nr 12, s. 28.

${ }^{33}$ Informacja o działalności agencji zatrudnienia w 2013 r. - ibidem, s. 18, z czego na podstawie umowy o pracę zatrudnionych było $43 \%$, zaś na podstawie umów cywilnoprawnych $57 \%$.

${ }_{34}$ Obliczenia własne na podstawie: T. Szulc, Praca w Polsce I-III 2014, http://www.egospodarka. pl/112456,Praca-w-Polsce-I-III-2014,1,39,1.html, [dostęp: 8.09.2014], s. 1. Autorka podaje, że pod koniec I kwartału 2014 r. liczba zatrudnionych w Polsce wynosiła ponad 11 mln. osób.

${ }^{35}$ Odczytany a contrario przepis art. 10 ust. 2 ustawy o zatrudnianiu pracowników tymczasowych pozwala wnioskować, że w przypadku zatrudnienia tymczasowego trwającego przez okres krótszy niż 6 miesięcy zasadniczo wyłączeniu uległa zasada udzielania urlopu wypoczynkowego w naturze, co w sposób istotny narusza zasadę prawa do odpoczynku pracownika tymczasowego. 
Sprawiedliwy stosunek pracy tymczasowej powinien równoważyć interesy obu jego stron. Teoretyczna równość wobec prawa została zagwarantowana, w praktyce jednak wydaje się przeważać ekonomiczny interes strony pracodawczej, a zatem agencji i pracodawcy użytkownika. Pracownik tymczasowy jest traktowany przedmiotowo - gdyby było inaczej, urzeczywistnienie w praktyce znajdowałyby uprawnienia przysługujące mu jako podmiotowi pracy.

W ciągu trzech dekad od wydania encykliki Laborem exercens ustrój społeczno-ekonomiczny, w którym kształtowały się stosunki pracy ulegał wielu przeobrażeniom. Ukazały one, że nie tylko państwo należy widzieć w roli pracodawcy pośredniego, o którym pisał Papież Jan Paweł II. Gwałtowne przeobrażenia gospodarcze skłaniają do poszukiwań coraz to nowych pracodawców pośrednich. Istotne wydaje się w dalszym ciągu pytanie, czy kształtują oni sprawiedliwe stosunki pracy, w których urzeczywistniane są obiektywne uprawnienia człowieka pracy. Odpowiedź na nie nadal czyni aktualną potrzebę podkreślania, że „pierwszą podstawą wartości pracy jest sam człowiek - jej podmiot” (LE 6). 